\title{
Modelos Neurais de Consciência: uMa ANÁlise NeUrofilosóficA ${ }^{1}$
}

\author{
Carlos Eduardo B. de Sousa ${ }^{2}$
}

\begin{abstract}
RESUMO: Modelos neurocognitivos têm sido propostos para investigar a consciência. O objetivo é responder à pergunta sobre como o cérebro é capaz de produzir estados conscientes qualitativos. Os modelos são representaçôes teóricas baseadas em algumas pesquisas empíricas. Contudo, a questão central, aparentemente trivial para alguns autores, refere-se à representatividade e confiabilidade dos modelos, i.e., saber se são capazes de explicar como a consciência emerge de processos neurais. Esses modelos são considerados como guia no estudo científico da consciência: os modelos cognitivos de Dennett (Multiple Draft) e Baars (Global Workspace), os modelos neurobiológicos de Edelman (Dynamic Core), Dehaene et al. (Global Neuronal), de Damásio (Somatic Markers Hypothesis), e o modelo neurodinâmico (Neurodynamic Model) proposto por Freeman. O presente texto visa a analisar a coerência e a plausibilidade dos modelos, i.e., se realmente explicam a "consciência" e suas propriedades em termos neurais ou se explicam apenas mecanismos neurobiológicos subjacentes no cérebro. O objetivo é avaliar escopo e limites dos modelos além da aplicabilidade na resoluçấo do problema da consciência.
\end{abstract}

PALAVRAS-CHAVE: Consciência. Modelos Neurocientíficos. Explicação. Neurobiologia.

\section{INTRODUÇÃO}

O problema da consciência ${ }^{3}$ possui origem na Filosofia Moderna. Por séculos, o assunto restringiu-se ao âmbito da filosofia. No entanto, houve uma mudança e, atualmente, discute-se sobre a possibilidade de uma ciência da consciência, i.e., como explicá-la cientificamente. A neurociência assumiu a tarefa de responder à questão de como o cérebro é capaz de gerar estados conscientes providos de qualidades singulares (cf. DE SOUSA, 2012, 2013). Para tanto, modelos neurais têm sido propostos. A partir desses modelos, alguns neurocientistas e filósofos visam a entender como o cérebro produz estados conscientes qualitativos. Todavia, alguns autores defendem, açodadamente,

\footnotetext{
${ }^{1}$ Agradeço ao avaliador anônimo que emitiu valiosos comentários provocando revisôes importantes no artigo.

2 Professor Associado, Laboratório de Cogniçâo e Linguagem, Centro de Ciências do Homem, Universidade Estadual do Norte Fluminense Darcy Ribeiro, Rio de Janeiro (UENF). Endereço para correspondência: UENF, CCH, LCL. Av. Alberto Lamego 2.000, CCH, sala 111, Horto, CEP, 28013-602 - Campos dos Goytacazes, RJ - Brasil. E-mail para correspondência: cdesousa@uenf.br.

${ }^{3}$ Tal como a tradição filosófica o identifica.
} 
hipóteses prima facie controversas, como da ausência de livre-arbítrio (cf. DE SOUSA, 2014).

Entretanto, uma leitura da história das ciências revelará disputas e obstáculos no desenvolvimento de teorias científicas que sugerem a adoção de certa parcimônia por parte dos envolvidos, pois teorias científicas são falíveis e corrigíveis. É preciso ter em mente que, em primeiro lugar, os neurocientistas deveriam admitir que uma "ciência da consciência" se encontra ainda em estágio inicial e, desse modo, requer mais pesquisas e discussão crítica (cf. DE SOUSA, 2013). Por outro lado, deve-se salientar que o intuito não é constranger as neurociências, mas chamar a atenção para o fato de que se está longe de uma solução para o problema da consciência. Apesar disso, o raciocínio não implica assumir que o problema jamais será solucionado. A meta de explicar a consciência a partir do arcabouço neurocientífico é desejável, mas ainda é prematuro argumentar em favor de posiçóes controversas como, por exemplo, defender a tese da ausência de livre-arbítrio (DE SOUSA, 2014).

Nos últimos anos do século XX, neurocientistas formularam modelos de consciência para dar suporte aos estudos. Contudo, existem filósofos que duvidam da capacidade de a neurociência explicar algo aparentemente de natureza distinta da de estados cerebrais. Um representante é David Chalmers (1996), o qual defende uma ontologia incomum, segundo a qual a consciência seria uma propriedade diferente do cérebro e, portanto, de natureza ontológica não-física. Assinala Chalmers:

A consciência escapa da rede de explicação redutiva, porque nenhuma explicação fornecida totalmente em termos físicos poderá dar conta da emergência da experiência consciente [...], consciência não é logicamente superveniente sobre o físico [...]; todos os micro-fatos físicos no mundo não implicam em fatos sobre a consciência. (CHALMERS, 1996, p. 83).

Por outro lado, neurocientistas e adeptos do empreendimento neurocientífico acreditam ser possível explicar a consciência em termos puramente neurobiológicos, visto que, em última instância, a consciência seria um fenômeno biológico (SEARLE, 2000; CRICK, 1994, REVONSUO, 2006, 2010). Chalmers se mostra cético sobre a possibilidade de uma ciência da consciência, ${ }^{4}$ e assume que "consciência" possui natureza sui generis,

\footnotetext{
${ }^{4}$ Apesar de Chalmers ser um dos fundadores e organizadores de uma das maiores conferências sobre a possibilidade de uma ciência da consciência, a Toward a Science of Consciousness (http://www. consciousness.arizona.edu/) que ocorre anualmente, tendo como base a Universidade do Arizona, em Tucson, Estados Unidos.
} 
distinta de eventos neurobiológicos e, como tal, não seria possível explicá-la cientificamente. A tese de Chalmers recebeu diversas críticas (cf. DE SOUSA, 2009) que partiram de outro pressuposto ontológico (naturalismo). Por ora, uma breve réplica basta: negar a possibilidade de uma ciência da consciência é um contrassenso e é intelectualmente irresponsável. As evidências de que a consciência é uma propriedade biológica do cérebro contradizem a tese de Chalmers; intervençôes cirúrgicas, introdução de substâncias químicas e estimulação eletromagnética transcraniana realizam mudanças nos estados conscientes já descritos na literatura (cf. BEAR et al., 2007; PURVES, 2008). As evidências servem de suporte para a formulação da hipótese de que estados conscientes são baseados na neurobiologia. Talvez alguns filósofos se sintam ameaçados pela tomada da última grande questáo da filosofia.

Não obstante a recusa de certos setores da filosofia, o interesse nos estudos sobre a consciência se expandiram e, desde a década de noventa do século XX, as neurociências se encarregaram da tarefa de explicar como o cérebro produz experiência consciente qualitativa. Todavia, é preciso reconhecer, acima de tudo, que estudar a consciência através do uso da metodologia das ciências físicas não equivale a estudar galáxias, montanhas, florestas, clima ou mesmo organismos não-humanos. A razão é que consciência, segundo a tradição filosófica, parece ser uma propriedade exclusiva do homem, de sorte que falar acerca da consciência significa falar sobre questóes que se relacionam diretamente com a vida diária de agentes racionais, volitivos, emotivos e autônomos. Antti Revonsuo expressa brilhantemente a fascinação pelo assunto:

O estudo da consciência é o estudo de um profundo mistério sobre nós mesmos. É o estudo da natureza de nossa existência, mas nâo o estudo de um tipo de existência que a física e outras ciências estudam [...]. Estudar a consciência é estudar a natureza fundamental de nossa experiência pessoal, nossa existência subjetiva, nossa vida como uma sequência de experiências subjetivas. (REVONSUO, 2010, Introdução).

Revonsuo enfatiza que o assunto toca no fundo de nossas convicçóes sobre nós mesmos e o que nos torna humanos. Uma concepção de humanidade secular encontra suporte na ideia de consciência livre e autônoma para se autodeterminar e agir no mundo (TUGENDHAT, 1997). Essa visão, no entanto, tem sido questionada pelas neurociências que, inter alia, almejam reduzir a consciência a estados neurobiológicos no cérebro, eliminando qualquer menção à volição, agência racional ou estados conscientes superiores (cf. DE 
SOUSA, 2014). O reducionismo é uma característica das ciências cujo foco é explicar fenômenos através da redução de propriedades superiores às partes localizadas em níveis mais básicos, num dado sistema (cf. CHAO; CHEN; MILLSTEIN, 2013; VAN RIEL, 2014). No caso em tela, trata-se de reduzir estados conscientes a estados neurais (BICKLE, 2003; CRICK; KOCH, 2003).

Contudo, o assunto está envolto em uma névoa que evita a visão clara (cf. WITTGENSTEIN, 1984). Há uma miscelânea de teses e posições que precisam de unificação e contextualização numa plataforma comum. Em primeiro lugar, dever-se-ia enquadrar a discussão no contexto filosófico, em particular, no âmbito da epistemologia e filosofia da ciência, que tem como tradição o estudo epistemológico do conhecimento científico $(\mathrm{O}$ que é o conhecimento científico? Como garantir a verdade deste conhecimento? O que é uma explicação?). Em segundo lugar, acomodar a questão dentro da biologia, em particular, no contexto das neurociências. Porém, as neurociências são ciências recentes, e exigem discussão filosófica, como as demais ciências (cf. DE SOUSA, 2013, 2014). Em outras palavras, o debate exige conhecimento filosófico sobre ontologia, epistemologia, metodologia e axiologia do conhecimento neurocientífico.

O crucial na discussão é ter em mente que indagaçôes filosóficas são inescapáveis; discutir ou não uma questão já pressupóe fazer filosofia, pois requer a apresentaçấo de um argumento em favor ou contra para debater ou não a questão. Argumentar e oferecer razóes são trabalhos dos filósofos, desde que Sócrates deu início a esse empreendimento. Por exemplo, discutir ou não sobre a existência de Deus já pressupóe um argumento em favor ou contra o início do debate; Por que debater sobre a existência de Deus? Possíveis respostas: porque... (uma razão em favor ou contra). Analogamente, discutir se as ciências são capazes ou não de explicar a consciência já pressupóe a apresentação de um argumento racional em favor ou contra a discussão da mesma; são as (neuro) ciências capazes de explicar a consciência? Possíveis respostas: sim ou não, porque (uma razão em favor ou contra). Ou seja, empreender ou não uma ciência da consciência pressupóe a indicação de razóes em favor ou contra, e envolve trabalho filosófico ab initio.

Diante do exposto, a filosofia é inexorável. As questôes com as quais se depara o estudioso interessado em estudar o problema da consciência subdividem-se em: (1) questóes ontológicas (e.g., o que é a consciência? Que tipo de entidade é a consciência?); (2) epistemológicas (e.g., como conhecer e explicar - formular uma teoria sobre a consciência?); (3) metodológicas 
(e.g., que tipo de método adotar, no estudo da consciência?); (4) e éticas (e.g., qual a consequência prática que o esclarecimento sobre a consciência poderá acarretar?). Existem outros pontos, mas essas perguntas já indicam a dificuldade em tratar de algo complexo. Tais questôes centrais precisam ser discutidas, e as possíveis respostas, caso sejam propostas, devem considerar diversos ângulos, e não apenas o ponto de vista filosófico ou científico, mas também prático.

Como de praxe, a tarefa inicial de qualquer investigação, seja filosófica, seja científica, é definir os termos com clareza e precisão. Ou seja, é preciso delimitar o objeto de estudo. Este texto visa a discutir a possibilidade de uma ciência da consciência a partir da análise de modelos neurais de consciência. A primeira parte é uma introdução à problemática, a segunda consiste da exposição de alguns modelos neurais de consciência. Por último, há uma breve análise dos modelos propostos por neurocientistas e filósofos.

\section{Breve Histórico}

O problema da consciência é considerado um dos últimos grandes temas da filosofia a ser investigado pelas ciências (BLACKMORE, 2006). A história da filosofia e das ciências (que não é linear) apresenta diversos exemplos de questóes que um dia eram tidas como filosóficas, mas que se tornaram objeto das ciências (e.g., a natureza do tempo, do movimento, da origem da vida, da composição da realidade etc.). Paulatinamente, algumas questôes encontraram tipos de explicação. Embora houvesse tentativas de se investigar a consciência sob o ponto de vista científico, no final do século XIX e início do século XX, com Sigmund Freud, Wilhelm Wundt, Gustav Fechner e William James, contudo, não foi possível prosseguir com esse objetivo, em virtude de uma mudança de rumo.

Com o advento do behaviorismo, no início do século XX, o estudo científico sobre a consciência foi removido do campo da ciência, permanecendo o assunto restrito ao âmbito da filosofia. Poucos cientistas se interessavam pelo tema, o que gerou um atraso de quase um século nas pesquisas (BAARS, 1997; CRICK, 1994). Damásio (2005) e Dehaene (2014) relatam a dificuldade em tentar estudar a consciência, cientificamente. De acordo com os autores, era proibido usar o termo "consciência" nos laboratórios e salas de aula. A razão era a visão científica dominante à época, a saber, o behaviorismo. Durante 
muito tempo, abordava-se o assunto através de estudos tangenciais, e.g., atenção, memória, e execução de tarefas conscientes.

Até o princípio do século XX, o único método de investigação era a introspecção (olhar para dentro), seja empregando o método cartesiano, seja aplicando o método da fenomenologia (cf. ZEMAN, 2004). Com o surgimento do behaviorismo, o método introspectivo e a tentativa de abordar estados conscientes internos foram rechaçados. $\mathrm{O}$ novo método da jovem ciência do comportamento consistia em observar o comportamento público segundo a regra "estímulo-resposta"; não interessavam as ocorrências internas da consciência. Salienta John Watson (1913), um dos expoentes do behaviorismo, no texto considerado o manifesto do movimento:

A psicologia como o behaviorista a vê é um ramo experimental puramente objetivo das ciências naturais. Seu objetivo teórico é a previsão e o controle do comportamento. A introspecção não constitui parte essencial de seus métodos, nem o valor científico de seus dados depende da facilidade com que eles podem ser interpretados em termos de consciência. O behaviorista, em seus esforços para conseguir um esquema unitário da resposta animal, não reconhece linha divisória entre homens e animais. [...] Parece ter chegado a hora em que a psicologia deve descartar toda referência à consciência; na qual ela não precisa mais enganar a si mesma pensando que pode tornar estados mentais objeto de observaçáo. Nós nos tornamos tão enredados em questôes especulativas concernindo os elementos da mente, a natureza do conteúdo consciente (por exemplo, pensamento sem imagem, atitudes e Bewussteinslage [estados de consciência sem relaçáo com sensaçóes] etc.) que eu, como um estudante experimental, sinto que algo está errado com nossas premissas e com os tipos de problemas os quais delas se desenvolvem. (WATSON, 1913/2008).

Como pode ser evidenciado na citação de Watson, behavioristas proibiam o uso da palavra "consciência", e, assim, a "caixa-preta" da consciência permaneceu - e ainda permanece - lacrada para as ciências, ficando o assunto restrito ao âmbito da filosofia. Foi somente no final do século XX que a questão atraiu o interesse de neurocientistas. $\mathrm{O}$ pioneiro foi o ganhador do Prêmio Nobel, Francis Crick (1994), o qual estipulou uma ruptura com a tradição filosófica, ao afirmar que a consciência é um fenômeno biológico e, 
portanto, deveria ser tratado do ponto de vista da biologia. No entanto, um dos primeiros a afirmar isso fora o filósofo John Searle (1992). ${ }^{5}$

\section{Definindo “ConsCIÊNCIA"}

$\mathrm{Na}$ verdade, Searle é o pioneiro (1992), porque introduziu a agenda de estudos científicos da consciência e estabeleceu como tarefa primeira entender o significado do conceito, visto que a compreensão de um conceito pode influenciar na resposta. Não obstante as dificuldades de se definir algo reconhecidamente táo complexo, como o conceito de consciência, é preciso isolar um núcleo semântico, e Searle faz isto; para ele, "consciência"

[s]ão simplesmente os estados subjetivos de sensibilidade (sentience) ou ciência (awareness) que começam quando uma pessoa acorda de manhá, depois de um sono sem sonhos, e se estendem por todo o dia até que vá dormir à noite, entre em coma, morra ou de algum outro modo se torne, digamos, "inconsciente". Acima de tudo, a consciência é um fenômeno biológico. Devemos concebê-la como parte de nossa história biológica comum, junto com a digestáo, o crescimento, a mitose e a meiose. (SEARLE, 2010, p. 1-2).

Searle identifica as propriedades inalienáveis da consciência: subjetividade, privacidade, qualia, unidade intencionalidade. Tais propriedades são aceitas por grande parte da comunidade de filósofos, embora existam vozes discordantes (cf. DENNETT, 1991, 2005). Além das características acima, o conceito de "consciência" engloba outras, o que o torna ambíguo devido aos diversos sentidos. Por exemplo, a habilidade de estar consciente de algo referese a "ter algo em mente", um determinado conteúdo mental. Usualmente, emprega-se a expressão "x está consciente de y", onde $x$ é um sujeito e $y$ é um conteúdo mental. Conteúdos mentais tipicamente vêm acompanhados de propriedades qualitativas conhecidas como "qualia" (do latim singular quale, que significa qualidade). Segundo alguns autores, qualia parecem não existir fisicamente, o que leva ao problema da consciência propriamente dito (JACKSON, 1982): como um órgão físico (o cérebro) pode produzir propriedades

\footnotetext{
${ }^{5}$ Searle esboça rudimentarmente sua teoria da consciência, no livro Intencionalidade, de 1983. Posteriormente, o autor publicou diversos textos relacionados ao tema, porém, tratando o assunto de modo periférico. Uma teoria mais elaborada da consciência é proposta por Searle em A Redescoberta da Mente, cujo ponto de partida é a biologia da consciência. Essa concepção de Searle é denominada naturalismo biológico. Em livro de 2010, Searle expande sua teoria.
} 
não-físicas (qualia)? No entanto, a pergunta é capciosa, visto que assume que qualia são ontologicamente distintos do cérebro.

Por outro lado, se qualia são propriedades vivenciadas fisicamente (por sujeitos que são, em última instância, agregados físico-químicos), por conseguinte, os qualia devem ser propriedades físico-químicas produzidas, sob certas condiçóes, pelo cérebro e vivenciadas subjetivamente por um sujeito. $\mathrm{O}$ erro está na formulação da pergunta que pressupóe uma ontologia dualista. $\mathrm{Se}$, ao contrário, se assumisse outra ontologia, a saber, de que qualia são propriedades biológicas (físico-químicas) produzidas pelo cérebro, então o problema mudaria de figura. Em outro lugar, De Sousa (2009) definiu qualia como propriedades biológicas (baseadas na físico-química) experienciadas subjetivamente. A condição necessária para vivenciar qualia é o organismo estar dotado de sistemas sensoriais, cérebro e interaçáo com o meio. A neurobiologia dos sistemas sensoriais é capaz de indicar o caminho para os estudos sobre os qualia, porque os sinais sensoriais (estímulos físico-químicos), ao serem captados, recebem as primeiras qualidades nas diferentes modalidades (visão, audição, olfato etc.), e, em seguida, os sinais eletroquímicos são enviados ao cérebro, onde recebem as qualidades exclusivas (DE SOUSA, 2009).

O ponto de partida deve ser a neurobiologia (pace Searle). Nesses moldes, "consciência" é um fenômeno subordinado à neurobiologia, haja vista o homo sapiens ser um organismo biológico (cf. SEARLE, 2000; REVONSUO, 2006; DE SOUSA, 2009). Prosseguindo, "consciência" refere-se à capacidade de ter conteúdos mentais qualitativos, no sentido de estar consciente ou atento para esses conteúdos, que são singulares. Conteúdos mentais possuem propriedades intencionais, pois são sobre algo (e.g., o pensamento sobre uma Ferrari é sobre uma Ferrari, e não sobre um Fusca). A intencionalidade é um atributo central de estados conscientes, mas existem outros: senciência, consciência como autoconsciência ou consciência de si, consciência como algo privado (pertencimento ao sujeito), consciência como transparência ou acesso (acessibilidade direta pelo sujeito, transparente para ele e opaca para uma terceira pessoa) e, finalmente, consciência como estados qualitativos (qualia) únicos.

\section{Identificação e Ataque ao Problema}

A partir das características supracitadas, o problema se afigura do seguinte modo: como mecanismos neurobiológicos (localizados em níveis 
básicos, como celular e molecular) são capazes de produzir propriedades superiores vivenciadas em nível fenomenal (ou subjetivo)? Tais propriedades possuem qualidades únicas e singulares. Alguns autores costumam relacionar o problema da consciência com o problema dos qualia, visto que estes são características inegáveis presentes em toda experiência consciente. Explicar os qualia seria equivalente a explicar a consciência. Porém, a controvérsia ao redor da questão não se aproxima do consenso.

Após a caracterização e identificação do problema, pode-se passar para a pesquisa empírica; nesse momento, entram em cena as neurociências, as quais visam a buscar uma resposta ancorada na neurobiologia. No entanto, as neurociências, como as ciências em geral, não admitem a existência de propriedades não-físicas; o foco de pesquisa é a referência direta às bases neurobiológicas. Logo, as neurociências possuem um caráter reducionista. Bickle (2003) afirma que o nível neurobiológico (celular e molecular) é o verdadeiro nível de investigação sobre a consciência, porque esta última é produzida por mecanismos neurobiológicos. Consequentemente, não há menção de conceitos mentais ou de estados conscientes, nas explicaçóes neurocientíficas.

A neurociência, como a maioria das ciências, almeja entender um fenômeno através da identificaçáo de mecanismos causais que permitam sua ocorrência. Em sistemas biológicos, mecanismos causais geralmente se encontram em níveis mais básicos (CHAO; CHEN; MILLSTEIN, 2013). Nesses termos, explicar a consciência seria equivalente a explicar mecanismos neurobiológicos, contudo, ainda não existe evidência suficiente e nem argumento racional em favor da redução ${ }^{6}$ (SULLIVAN, 2009).

Não obstante, neurocientistas e interessados no assunto estabeleceram alguns pressupostos para desenvolver uma ciência da consciência que tente compatibilizar subjetividade com objetividade científica. Todavia, essa é uma falsa dicotomia, pois sugere uma contraposição entre subjetividade e objetividade. Tal visão também não é plausível, porque a ciência é um empreendimento humano iniciado na mente consciente do cientista e, por essa razão, "objetividade científica" deve ser entendida como intersubjetividade. A comunidade de cientistas estabelece,

\footnotetext{
${ }^{6} \mathrm{O}$ reducionismo é uma visão aceita pelos cientistas, porém, se mostra frágil devido à falta de suporte experimental (dados empíricos robustos) que confirmem a redução de conceitos, entidades e níveis a outros. Além disso, a multiplicidade de métodos presente nas ciências revela divergências na forma de investigar e explicar fenômenos naturais. Na maioria dos casos, os dados divergem, ao se adotar metodologia diferente (cf. SULLIVAN, 2009; UTTAL, 2012; VAN RIEL, 2014).
} 
segundo regras (o suposto "método"), o que vale como verdade ou falsidade e, nesses moldes, objetividade científica deve ser concebida como concordância intersubjetiva (cf. VELMANS, 2009). Geralmente cientistas adotam métodos e ferramentas próprias para lidar com os problemas como, por exemplo, a construçáo de modelos. Grosso modo, um modelo consiste em uma descrição teórica de um determinado fenômeno; um exemplo são os modelos atômico de Bohr e da estrutura de DNA, de Crick e Watson.

Modelos científicos têm a função de representar da forma mais fiel possível o fenômeno em estudo, e são construídos a partir de observaçáo e testes. Certos modelos são idealizaçôes e objetivam ser uma representação acurada de aspectos relacionados com o fenômeno em estudo. A formulação de modelos baseia-se em conhecimento prévio, teorizaçóes e experimentação. Os modelos servem como tentativas para conectar a teoria com o fenômeno. No entanto, há dificuldades relacionadas com a formulação, representatividade, $\mathrm{e}$ confiabilidade dos dados produzidos a partir dos modelos, mas este tópico não será abordado aqui. ${ }^{7}$ Apesar disso, é amplamente reconhecida a importância e o papel dos modelos na prática científica (cf. FRIGG; HARTMANN, 2012).

A neurociência, ao abordar o fenômeno da consciência, usa modelos teóricos e computacionais. Com base em descobertas recentes, alguns neurocientistas propuseram modelos neurais para estudar a consciência. A ideia subjacente é que a consciência constitui um fenômeno biológico complexo implementado pelo/no cérebro por grupos de neurônios e, portanto, entender a consciência consiste, fundamentalmente, em entender como os neurônios funcionam. O pressuposto teórico é a doutrina neuronal, i.e., a tese de que neurônios são a base do comportamento consciente e a unidade funcional principal do encéfalo e, portanto, o locus de investigação (SHEPHERD, 1991). O próprio nome da disciplina sugere essa ideia: "neurociência" ou ciência dos neurônios.

Os modelos neurocientíficos de consciência mais conhecidos na literatura são (1) Multiple Draft (Dennett), (2) Somatic Markers (Damásio), (3) Neurodinâmico (Freeman), (4) Global Workspace (Baars), Global Neuronal Workspace (Dehaene et al.) e (5) Núcleo Dinâmico (Edelman). Nas próximas seçôes, há breve exposição dos modelos e, em seguida, uma avaliação da

${ }^{7}$ Uttal (2012) executa tal análise e conclui que a maioria dos dados gerados em modelos computacionais das neurociências é discrepante e subavaliado. $\mathrm{O}$ autor aponta diversas falhas em experimentos neurocientíficos, as quais podem comprometer o empreendimento. 
plausibilidade, coerência e aplicabilidade, ou seja, se os modelos de fato servem àquilo que se propóem, a saber, explicar a consciência. ${ }^{8}$

\section{Dennett: Multiple DRAFT Model}

O Multiple Draft Model ou Modelo de Múltiplos Esboços é proposto pelo filósofo Daniel Dennett (1991, 2005, 2007) e está baseado em experimentos das ciências cognitivas. $\mathrm{O}$ autor, apesar de afirmar que "explica a consciência”, exclui da descrição justamente os qualia. A razão é que Dennett visa a recusar uma concepção tradicional de consciência atribuída a René Descartes. Dennett não usa neurobiologia para sustentar suas afirmaçóes, mas experimentos das ciências cognitivas, aplicando várias metáforas. $\mathrm{O}$ objetivo do autor é solapar o chamado Teatro Cartesiano, que estabelece a necessidade da existência de um $e u$ ou homúnculo localizado em algum lugar no cérebro, que observa e comanda o comportamento (DENNETT, 1991, p. 107).

Dennett constrói o modelo a partir da ideia de "ediçáao"; em sua concepção, o cérebro seria um editor de informaçóes, e não um tipo de máquina de representação cujo pressuposto é a existência de um expectador que assiste às representaçóes, tal como estabeleceria o teatro cartesiano. Como estamos em constante contato com o meio externo, recebemos informação em tempo real e irrestrito, por meio da percepção, e essa informação é processada no cérebro por redes especializadas. Redes neurais (editores) interpretam as informaçôes enviadas por diversas trilhas para outras redes, as quais vão elaborando narrativas num processo indefinido de processamento e interpretação, resultando em múltiplos esboços. O termo "esboço" (draft) é utilizado para transmitir a ideia de processo recursivo cujo objetivo é a edição constante. Porém, é preciso enfatizar que não há um sujeito da experiência, mas somente diferentes níveis de processamento de informação.

O cérebro, por conseguinte, na concepção dennettiana, trabalha como um editor, escrevendo e reescrevendo estórias (story) segundo informaçóes captadas no meio. A tarefa do pesquisador da consciência consiste em descrever os processos, empregando o método da heterofenomenologia ou "fenomenologia

\footnotetext{
${ }^{8}$ Devido à limitação de espaço, tentarei sintetizar os modelos através da apresentação de características centrais. Os modelos são mais elaborados do que a exposição feita aqui. Para melhor entendimento sobre os modelos de consciência discutidos no texto, sugiro a leitura dos textos originais elencados nas referências.
} 
do outro", nas palavras do autor. ${ }^{9}$ O sujeito é treinado a descrever seus estados internos para o pesquisador que os registra. Os dados brutos registrados são interpretados e recebem significados. Em seguida, entra em cena a "postura intencional" do investigador, que trata o sujeito como se fosse crente (believer) e desejador (desirer). O procedimento envolve observação do comportamento e emprego de máquinas (EEG, PET, fMRI). De acordo com Dennett, a narrativa construída retrata exatamente o que ocorre na consciência do sujeito.

Após receber críticas (cf. DAHLBOM, 1995), Dennett substituiu sua concepção de múltiplos esboços pela ideia de "fama" no cérebro. Como a fama é transiente, Dennett argumenta que a informação no cérebro é equivalente à fama, que é transitória e, analogamente, essa narrativa muda de acordo com a informação entrante. As narrativas carregam informação atualizadas a cada instante. $\mathrm{O}$ heterofenomenologista deve apenas registrar o que o sujeito relata.

Um olhar mais atento revela que o modelo de Dennett explica apenas discriminaçóes perceptivas e não lida com a consciência fenomenal e suas qualidades; Dennett toma como objeto apenas as bases cognitivas, i.e., a captaçáo das informaçóes no meio pelos sistemas sensório-perceptivos. $\mathrm{O}$ autor não aborda o nível fenomenal onde as qualidades subjetivas emergem, e o motivo é a suposta inexistência de tais qualidades subjetivas. $\mathrm{O}$ autor assume que o nível de processamento é o nível da consciência, mas a história que ele conta está incompleta. Críticos asseveram (cf. DAHLBOM, 1995) que Dennett pode até estar certo em sua descrição funcional, todavia, somente no que concerne ao nível cognitivo, que é a base da consciência. Sua narrativa não contempla a consciência propriamente dita (qualia) (DE SOUSA, 2009) e, portanto, é incompleta. Além disso, Dennett exclui exatamente aquilo que se quer saber, i.e., como as propriedades qualitativas emergem de processos neurobiológicos.

\section{Damásio: Somatic Marker Hypothesis}

O neurologista Antonio Damásio (2005) vem trabalhando numa hipótese a partir de sua experiência com pacientes com danos neurológicos. $\mathrm{O}$ modelo de Damásio tem a vantagem de ser estabelecido em bases neurobiológicas. O termo Somatic Marker Hypothesis, o qual pode ser traduzido como Hipótese do Marcador Somático, divide a consciência em dois tipos: central e ampliada. Os dois modos baseiam-se num conjunto de atividades

\footnotetext{
${ }^{9} \mathrm{Na}$ visão dennettiana, esta é a ciência da consciência possível.
} 
neurobiológicas automatizadas que, concatenadas, dão origem a um self. Para Damásio, esse selfé o experienciador, aquele que "vê um filme na mente".

Damásio estipula a participação de diversas partes neuroanatômicas do organismo no processo de criação da consciência: sistemas de memória, límbico, amígdala, e cerebelo. Essas estruturas dão suporte para os mecanismos superiores, na regiáo tálamo-cortical. Segundo o autor, o processo é mediado por marcadores somáticos, mecanismos de associaçóes entre estímulos que reforçam e induzem o estado fisiológico afetivo. Eles são os mecanismos de relação no cérebro que direcionam a atenção para certas situaçóes.

A consciência começa, nesse modelo, quando se vivencia um sentimento de que algo acontece, no interior e exterior do organismo, e esse sentimento é acompanhado de imagens - visual, auditiva, tátil, visceral - que possuem qualidades específicas. Damásio admite que os qualia são centrais para a explicação da consciência, e tenta acomodá-los na hipótese. Através dos mecanismos neurobiológicos supracitados, uma consciência central emerge e se caracteriza pelo estado de vigília com uma emoçáo de fundo e atenção básica. Esses mecanismos produzem um sentimento primitivo no organismo (e estariam presentes em várias espécies). $\mathrm{O}$ sentimento adquire sentido, quando é associado (aplicado) à linguagem e (relacionado) à memória, produzindo um relato imagético.

Damásio afirma que o cérebro vai construir um relato desse sentimento. Conforme o cérebro forma imagens de um objeto, essas imagens vão sendo relacionadas a diversos outros mecanismos, até que se transformem num relato significativo continuado, de sorte que, sugere Damásio, emerge um self que observa, interpreta e vivencia. Esta é a consciência ampliada, quando o organismo se encontra consciente de si e do meio em que está inserido, produzindo, assim, conhecimento.

Tal processo é descrito por Damásio em detalhes, e pressupóe diversas etapas para que a consciência ampliada possa emergir. Mas em nenhum momento se vê uma explicaçáo causal de como algo neurobiológico se torna subjetivo, embora Damásio sustente que há a passagem do nível biológico da consciência central, para o nível do proto-self e, em seguida, para o nível mais complexo, da consciência ampliada onde o selfé o resultado. O modelo, mesmo apoiado em conhecimento neurobiológico, é, não obstante, esquemático e idealizado. $\mathrm{O}$ autor estipula que algumas partes interagem aparentemente de modo causal. No entanto, é difícil ver causação real. A descrição de Damásio 
sobre como os mecanismos geram a consciência ampliada identifica apenas algumas correlaçóes entre certos eventos, sem apontar causas reais, i.e., como algo surge a partir de outro algo.

Como o próprio autor afirma, pode parecer um truque que transforma a descrição objetiva em subjetiva, quando diversos eventos neurobiológicos complexos produzem um salto qualitativo. Mas esse salto teórico não encontra suporte empírico. As descriçóes neurobiológicas podem até ser verdadeiras empiricamente, todavia, daí concluir que causam a consciência é equivalente a saltar à distância com pernas curtas. O truque termina, enfatiza Damásio, quando a memória entra em jogo, produzindo um self autobiográfico e mantendo esse self ativo.

Em suma, a consciência ampliada consiste da capacidade de estar consciente de uma gama de entidades e eventos. A ideia de Damásio é que o cérebro contém um modelo de si mesmo, o que parece algo estranho, porque não está claro como algo pode conter em si mesmo um modelo de si mesmo sem que ocorra confusão de identidade. Conforme o autor, esse modelo:

[é] uma coleção de mecanismos cerebrais cuja principal tarefa é a gestáo automatizada da vida do organismo [...] a gestáo da vida realiza-se graças a uma variedade de ações regulatórias estabelecidas de modo inato - secreção de substâncias químicas como hormônios, assim como movimentos propriamente ditos das vísceras e dos membros. A mobilização dessas açôes depende das informaçôes fornecidas por mapas neurais próximos que sinalizam, momento a momento, o estado de todo organismo. É importantíssimo o fato de que nem os mecanismos reguladores da vida, nem seus mapas corporais são os geradores da consciência, embora sua presença seja indispensável para mecanismos que realmente realizam a consciência central. (DAMÁSIO, 2005, p. 42).

\section{Freeman: Modelo NeUrodinâmico}

Walter Freeman (2001) propóe o modelo neurodinâmico, baseado na teoria de sistemas dinâmicos. ${ }^{10}$ Segundo Freeman, o cérebro seria um artefato

\footnotetext{
${ }^{10}$ Sistemas dinâmicos consistem de um conjunto de variáveis que descrevem a trajetória de estados ou fases, e são compostos por espaços de fases ou estados que obedecem a certas regras de transição. Um único estado pode evoluir (mudar durante o tempo) para vários estados. Esse processo pode ser calculado deterministicamente, usando-se cálculos probabilísticos que apontem para um espaço com diversas possibilidades de estados, durante a evolução no tempo (cf. MEISS, J. 2007, Dynamical systems. Scholarpedia, v. 2, n. 2, p. 1629. Disponível em http://www.scholarpedia.org/article/ Dynamical_systems. Acesso em: 08/07/2014.
} 
dinâmico, oscilando entre diferentes estados de acordo com a informação que entra através dos sistemas sensoriais. Freeman, sabiamente, reconhece que o cérebro é uma estrutura cuja função é alcançar um estado de equilíbrio por meio da avaliação da informação presente. $\mathrm{O}$ autor se opôe à visão localizacionista ${ }^{11}$ nas neurociências. Para Freeman, o cérebro é uma estrutura adaptativa que, a cada instante, tenta compensar as mudanças de estados e reduzir a entropia com a criação de imagens dinâmicas. Freeman aplica teoria dos atratores (caos) para explicar o comportamento dinâmico dos neurônios, i.e., como se comportam, gerando estados neurodinâmicos conforme estimulação externa e interna.

O corpo é composto por assembleias de células integradas (redes neurais), e cada uma é um agente autônomo o qual produz estados dinâmicos locais (segundo os princípios da eletroquímica). Assembleias neurais produzem estados dinâmicos e constrangem seus vizinhos, provocando competição entre redes neurais. $\mathrm{O}$ resultado desse processo são ocorrências de estados transientes. De acordo com Freeman, o cérebro cria representaçóes do mundo para si mesmo por meio da queima de energia (como num sistema termodinâmico), construindo imagens mentais. A base desse processo é a codificação da informação em padróes neurais (ativação e sincronização).

A fim de simplificar o modelo que é matematizado, Freeman usa uma analogia para introduzir a ideia de sistemas dinâmicos:

O cérebro é como um sistema caótico; imagine passageiros aguardando a chamada para o vôo num aeroporto: padrôes (estados como passageiros sentados no saguấo) mudam quando há uma chamada para seu vôo, e todos rumam numa marcha não-linear direcionada para o portão de embarque a fim de acomodarem-se em seus assentos no avião. (FREEMAN, 2001, p. 9).

Para Freeman, quando os passageiros se acomodam em seus assentos, equivale a dizer que o sistema chegou a um estado de estabilidade (ponto de equilíbrio). Analogamente, o cérebro (as redes neurais) se comporta como esse sistema aeroportuário; a cada mudança no estado atual do mundo, há uma mudança concomitante no cérebro, que tende a estabilizar as representaçóes. O ponto de partida é o meio ambiente onde o organismo está inserido; como os estados do meio mudam e se sobrepóem, o cérebro tenta gerar

\footnotetext{
${ }^{11}$ A ideia de que o cérebro é uma estrutura modular rígida com partes empenhadas em processar certos estímulos.
} 
entendimento para garantir a sobrevivência do organismo e detecta qualquer mudança (por meio dos sistemas sensoriais) e, a seguir, através de cálculos inconscientes, atribui valores que serão a base das imagens dinâmicas. Há um processo constante de atualização dos estados do meio, o qual tem como resultante a geração de campos dinâmicos devido às atividades neuronais que se influenciam mutuamente, dando origem a estados neurodinâmicos globais transientes. Na concepção de Freeman, o sistema neuronal se auto-organiza segundo estímulos específicos, e a atividade produz campos dinâmicos detectáveis em aparelhos como EEG e PET.

Os estados neurodinâmicos possuem padrão de atividade único e desencadeiam uma cascata de processos causais que culmina na geração de uma Global Amplitude Modulation (GAM) ou modulação global da amplitude. $\mathrm{O}$ processo, de acordo com Freeman, é não-linear e regido pelo caos. A consciência emerge, quando a GAM se dissemina pelo cérebro, produzindo estados de ciência (awareness), que são, por sua vez, vivenciados fenomenologicamente. Processos neurodinâmicos no cérebro originam estados conscientes que interpretam o mundo linearmente, atribuindo causas no mundo onde só aparecem correlaçôes. Populaçôes neurais interagem de modo causal, continuamente, criando padróes locais de atividade caótica os quais são disseminados por todo o cérebro, dando origem a estados globais de modulação de amplitude. As atividades neurais constrangem os estados, provocando instabilidade, o que leva à geração de um novo estado global, e assim sucessivamente. A estabilidade é momentânea, até que surja um novo padrão detectado pelos sistemas sensoriais, quando o processo se repete.

No entanto, Freeman reconhece a dificuldade em identificar como estados neurodinâmicos produzem consciência. $\mathrm{O}$ autor revela certa resignação, ao admitir que a única coisa que se pode fazer é identificar correspondências (correlatos neurais) entre atividades cerebrais e a experiência. Além disso, Freeman estipula, como meta inicial para estudar o assunto, o entendimento da natureza da causação. De fato, entender a causação deveria ser o primeiro passo para evitar a identificaçáo de meras correlaçóes. Poucos autores se concentram em investigar a causalidade e como o cérebro é capaz de causar o comportamento. A maioria assume que o cérebro causa o comportamento, como se fosse algo autoevidente e, nessa perspectiva, saltam para suas narrativas cuja aceitação requer atos de fé. $\mathrm{O}$ assunto merece atenção, pois causalidade é um tema primordial nas neurociências, ainda pouco discutido. Freeman 
é uma exceção, introduzindo o que considera como causação e admitindo, inclusive, que apontar correlaçóes não equivale a identificar causas.

Em outro lugar, discuto o problema da causalidade nas neurociências; por ora, basta entender o que Freeman defende, a saber, que causação consiste da atribuição de causas por agentes que produzem modificaçóes no mundo. Freeman adota a visão de David Hume de que as causas não estão no mundo, mas na mente dos sujeitos, os quais possuem uma predisposição em atribuir causas a eventos mundanos. Para Freeman, a razão é que, embora o cérebro seja regido por processos causais náo-lineares em nível celular, a compreensão dos eventos externos ocorre linearmente na consciência. $\mathrm{O}$ cérebro é regido pelo caos, mas entende o mundo de modo linear, porque o sujeito tem de entender os eventos serialmente. Porém, o entendimento de como o cérebro funciona exige o domínio de neurodinâmica, pois as redes neurais se ativam segundo os princípios da teoria dinâmica; redes neurais são relacionais e organizam-se de acordo com as interaçóes com o meio, de maneira a levar à produção de estados neurodinâmicos transientes.

\section{Edelman: Modelo do NúCleo Dinâmico (INTEgraÇáo de InformaÇão)}

O modelo do núcleo dinâmico de Gerald Edelman (1989, 2000) também é baseado em sistemas dinâmicos e inclui ainda, a teoria da seleção de grupos neuronais ou darwinismo neural. Edelman desenvolveu essa teoria (1989) para explicar como grupos neurais se organizam segundo o princípio da seleção natural. Grupos de neurônios produzem padrôes de atividades elétricas características, gerando uma organização única de assembleias neurais. Através de experiências, esses grupos neurais vão sendo selecionados e organizados de acordo com a especificidade do estímulo.

A tese de Edelman é de que grupos funcionais no sistema tálamocortical (mecanismos neurais) se conectam às áreas mais profundas do cérebro, formando um mapa neural único. Os grupos neurais auto-organizados constituem um núcleo dinâmico de conectividade reentrante. As atividades nesses núcleos produzem uma sucessão de estados diferenciados informativos e metaestáveis. A reentrância consiste de ciclos de sinalizaçôes (ativações neurais) ocorrendo no córtex (no sistema tálamo-cortical ligado a diferentes áreas do cérebro, por meio de longos axônios); essas ocorrências iteram-se e propagam-se pelas redes neurais como um sistema de propagação biofeedback (retroalimentação). 
Na visão de Edelman, neurônios que ativam juntos organizamse juntos. O resultado é o agrupamento de neurônios formando um núcleo dinâmico especializado, devido à proximidade e especialização em processar determinados tipos de informação. Esse núcleo neuronal mantém relações com áreas mais distantes, formando grupos ou assembleias neurais maiores. Consciência, nesse modelo, refere-se à capacidade de grupos neurais específicos de integrar informação em conjunção com habilidades semânticas e linguísticas. Através da reentrância, ocorre a sincronização das atividades de diversos grupos neurais mobilizados para processar um determinado tipo de informação. Quando essa informação é integrada em diferentes áreas em virtude da reentrância, há, para Edelman, um estado consciente. Consciência, de acordo com Edelman, está associada à complexidade neural, i.e., processamento e integração de informação em redes neurais que formam um núcleo dinâmico de processamento.

A reentrância é a chave do modelo, porque ela distribui a informação pelo sistema neural, quebrando a modularidade do cérebro e tornando a informação disponível para diferentes módulos. A consciência resulta da integração da informação e da interação neural, ocorrendo em diversos níveis de organizaçáo, sem que haja um eu ou comando central. Nas palavras de Edelman e Tononi:

A hipótese (do núcleo dinâmico) afirma que a atividade de um grupo de neurônios pode contribuir diretamente para a experiência consciente se ela for parte de um grupo funcional, caracterizado por fortes interaçóes mútuas entre um conjunto de grupos neuronais acima de um período de 100 milissegundos. Para que a experiência consciente se sustente, é essencial que esse grupo funcional seja altamente diferenciado, como indicado por altos valores de complexidade. Tal grupo (cluster) chamamos de "núcleo dinâmico" por causa de sua composição sempre alterável (ever-changing) além da integração ocorrente, que é gerada amplamente, embora não exclusivamente, dentro do sistema tálamo-cortical [...] a hipótese do núcleo dinâmico explica [...] as propriedades da experiência consciente por meio da ligação destas propriedades a processos neurais específicos que podem originar aquelas (propriedades). (EDELMAN; TONONI, 2000, p. 139-140). 
Edelman trabalha em parceria com Giulio Tononi, neurocientista computacional que desenvolveu o modelo computacional de integração de informação. Porém, o modelo é muito abstrato e requer o domínio de matemática avançada, o que torna o modelo idealizado e distante da realidade da neurobiologia em que Edelman quer se basear.

\section{Modelo Global Neuronal Workspace}

Global Workspace e Global Neuronal Workspace ou Modelo do Espaço Global Neuronal de Trabalho, foi proposto, inicialmente, por Bernard Baars (1988, 1997, 2002) e aperfeiçoado por Stanislas Dehaene et al. (2001, 2003, 2006, 2007). O modelo combina resultados práticos da neurociência com pressupostos teóricos das ciências cognitivas. A Global Workspace é uma arquitetura cognitiva desenvolvida há quase 20 anos por Baars e, grosso modo, consiste de um conjunto de módulos (redes neurais) especializados no processamento de informação. Baars assume que as redes neurais competem ou cooperam, a fim de enviar a informação para uma plataforma consciente (a Global Workspace). A Global Workspace surge a partir da ativação de diversas redes. A informação que alcança o espaço consciente da Global Workspace é disponibilizada para todo o sistema e, com isso, o sujeito acessa a informação.

O modelo de Baars é meramente teórico e funda-se em ciência cognitiva clássica. Baars não recorre à neurobiologia. Entretanto, a ideia parece boa, mas faltava a Baars tornar o modelo compatível com a neurobiologia corrente. A fim de complementar o modelo, através da integração de dados empíricos da neurobiologia, Dehaene et al. aplicaram diversos resultados recentes da neurociência da atençáo e memória, experimentos com visão cega, conhecimentos atuais de neurodinâmica e neuroanatomia, de sorte a mostrar como determinadas áreas no cérebro se ativam durante a execução de tarefas conscientes, formando um espaço neuronal. Os autores assumem que a Global Neuronal Workspace consiste de um conjunto de mecanismos neurobiológicos interconectados via neurônios com longos axônios (piramidal). Essa interconectividade de longa distância (neurônios localizados no sistema córtico-cortical e tálamo-cortical) faz com que todo cérebro esteja "interligado". A interconectividade é a chave no modelo, pois permite a interação entre diversos sistemas neurais espalhados pelo cérebro.

Do ponto de vista formal, o modelo é mais plausível, porque integra diversos mecanismos neurobiológicos, em particular, atribui papel central ao 
mecanismo de atenção de cima para baixo (top-down). A atenção desempenha papel fundamental, já que modula e aumenta a ativação neural, rompendo a modularidade e fazendo com que as redes se voltem para a informação prestes a entrar na Global Neuronal Workspace. Esta última é um espaço transiente sustentado pela ativação sincronizada de diversas redes neuronais. Como preveem Baars e Dehaene, a informação sensorial é enviada para esse espaço e se torna acessível para o sujeito. Ambos os modelos estabelecem que o acesso à informação no espaço consciente é a consciência do sujeito.

Um exemplo é a visão consciente; quando o sujeito recebe um estímulo visual, um conjunto de módulos neurais especializados em processar certas características, como localização e posição espaço-temporal, forma, profundidade, cor, contexto, é mobilizado para o processamento do estímulo. Ao final do processo, a informação ganha acesso ao espaço consciente e é amplificada pelas redes atencionais que aumentam (boost) a ativação. $\mathrm{O}$ resultado é a disponibilidade da informação consciente para diversas redes neurais no cérebro, garantindo o acesso global pelo Global Neuronal Workspace. Participam desse processo outros sistemas neurobiológicos, tais como o sistema de avaliação, recompensa e de memória, que atribui maior significatividade à informação disponível no espaço consciente.

Mecanismos de atenção de cima para baixo (ligados por longos axônios tálamo-corticais) distribuem a informação por todo o córtex cerebral, levando-a até as partes mais profundas do tálamo, onde se localiza o sistema límbico (supostamente responsável pelo controle das emoçôes) e a memória de longoprazo (hipocampo). De acordo com os autores, o modelo pode ser confirmado na prática; Dehaene e colegas executaram diversos testes e verificaram que esses sistemas se encontram ativos durante a execução de tarefas conscientes específicas (como cálculo matemático), demonstrando que há uma mobilização de várias áreas do cérebro, durante a experiência consciente, o que pode ser evidenciado pela medição com instrumentos (EEG, FMRI e PET).

O princípio subjacente aqui é a sincronização das redes neurais, ${ }^{12}$ um achado recente de Wolf Singer (1999). Neurônios ativados geram campos elétricos os quais se propagam pelas redes, produzindo sincronia neuronal (ativação em conjunto). A atividade neuronal sincronizada faz emergir um espaço consciente sustentado por diversas redes em sincronização. Essa ativação sincronizada pode ser captada empregando-se EEG, fMRI e PET. Decerto

${ }^{12}$ Atividades oscilatórias periódicas auto-organizadas existentes em determinados sistemas, os quais podem ser fásicos (momentos conjugados correspondentes) ou antifásicos. 
o modelo também apresenta mais detalhes do que os expostos aqui, mas a ideia principal é que um conjunto de neurônios ativados e em sincronização produz e sustenta transitoriamente esse espaço consciente, onde a informação sensorial ganha acesso, quando redes atencionais entram em cena. Atenção ou foco na informaçáo gera o acesso, e Dehaene afirma que esse acesso é a consciência do sujeito.

O modelo parece explicar de modo plausível certas funçóes da consciência. Contudo, não consegue resolver o problema das qualidades da experiência subjetiva, os qualia. $\mathrm{Na}$ verdade, o próprio autor não acredita ser possível existir qualia, pois o máximo que o modelo possibilita é acesso consciente. Entretanto, Dehaene deveria admitir que acesso em si não garante a aparição das qualidades que podem e devem ser acomodadas em qualquer modelo candidato a explicar como o cérebro produz consciência. Numa tentativa de integrar os qualia no modelo de Dehaene, De Sousa (2009) desenvolveu uma proposta em que a emergência de qualia pode ser garantida; o requisito é um mecanismo extra de associação entre áreas específicas. Em linhas gerais, bastaria admitir que o sistema sensorial, através das diferentes modalidades, já aplica, no momento da detecção do estímulo físico-químico, qualidades específicas (e.g., quente ou gelado, áspero ou liso, doce ou salgado, alta ou baixa intensidade etc.). $\mathrm{O}$ mesmo estímulo, ao ser enviado para as diversas redes neurais especializadas (hipocampo e amídala), receberia qualidades posteriores (relação com o sistema de memória e avaliação). As qualidades dependeriam da associação com os sistemas neurobiológicos estabelecidos pelo modelo (avaliação, recompensa, memória e emoçáo), mais a interconectividade com hipocampo e amídala. Durante esse processo, o estímulo sensorial receberia as qualidades únicas presentes na experiência consciente subjetiva, haja vista cada sistema de memória, de avaliação e de emoção ser único em cada sujeito (cf. DE SOUSA, 2009).

Contudo, é preciso admitir que o modelo ainda é incipiente e limitado, exigindo mais pesquisa teórica e empírica. No entanto, parece promissor, pois reúne condiçóes mínimas para abordar o problema da consciência. Bastaria acrescentar alguns pontos e convencer seus autores de que devem acomodar os qualia no modelo, do contrário, a explicação sobre a emergência da consciência de eventos neurais está incompleta. 


\section{Avaliação dos Modelos}

Após breve exposição dos modelos-candidatos a explicar como o cérebro produz consciência, esta seçấo avaliará a aplicabilidade e plausibilidade dos mesmos. A primeira pergunta é: esses modelos de consciência servem àquilo que se propóem, a saber, explicar a consciência? O que se entende por "consciência" pode ser explicado ou, pelo menos, acomodado nos modelos? Considerem-se, em primeiro lugar, as características compartilhadas pelos modelos. A primeira é a adoção do conceito de "informação". A segunda é a tese ontológica da doutrina neural, a ideia de que o neurônio é a unidade de processamento de informação. A terceira é o princípio da interconectividade neural. A quarta, a tese ontológica da modularidade do cérebro, e a quinta, o princípio da distributividade da informação pelo cérebro. Cabe mencionar que está implícita a tese fisicalista de que o cérebro é físico e o causador da consciência.

À primeira vista, os modelos descrevem processos especializados de processamento de informaçáo e coadunam a ideia de que a informação se distribui pelas redes devido à interconectividade neural. A ativação de redes neurais específicas distribui a informação pelo cérebro e, com isso, parece emergir um espaço consciente onde é gerado o acesso. Alguns autores chegam a afirmar que esse acesso é a consciência. Teoricamente, as descriçóes parecem plausíveis, pois, apesar de serem concorrentes, os modelos adotam as mesmas estratégias e conceitos. Por essa razão, os modelos também possuem inerentemente as mesmas falhas: incompletude, idealização extrema, ausência de qualia, uso indiscriminado do conceito de informaçáo, e um salto no escuro, i.e., "pular" do nível da neurobiologia para o nível subjetivo (de estados conscientes), sem apontar os estágios necessários que levam à geração dos estados conscientes. Os autores pressupóem certa condescendência do leitor, que deve adotar, pelo menos, o princípio de caridade. ${ }^{13}$

Não obstante, há autores que admitem explicitamente que os modelos de fato descrevem como a consciência é produzida pelo cérebro. No entanto, nesse caso, trata-se de convencimento por persuasão (um ato de fé), em vez de argumentação racional segundo evidências empíricas. Essa dicotomia (a diferença entre crença e certeza) foi discutida por Wittgenstein (1984); a crença pressupóe provar que se sabe, indicando a possibilidade de estar errado (dúvidas); certezas por sua vez, são fixas e dificilmente mudam, não se admitindo a possibilidade do erro. Os defensores dos modelos e seus

13 Princípio metodológico de interpretação e compreensão que atribui racionalidade à fala ou argumento de outrem, antes de uma avaliação crítica. 
seguidores têm a certeza de que os modelos descrevem a consciência (a exceção é Freeman), contudo, certezas, geralmente estão fora de dúvida, e a atitude científica tem como característica central a possibilidade da dúvida.

A crença, por outro lado, é expressa em proposições e pode ser verdadeira ou falsa, bastando adotar uma teoria da verdade. Já a certeza está fora de dúvida, porque são convicçôes difíceis de modificar. Em outras palavras, há poucos dados empíricos os quais sustentam os modelos, e há muita intuição sendo usada como argumento. Isso não parece ser "científico", tal como os próprios cientistas costumam defender, i.e., baseados em vasta experimentação, em dados seguros e discussão crítica. $\mathrm{O}$ falibilismo ou admissão da possibilidade do erro é central nas ciências e permite o avanço científico, quando uma teoria equivocada é corrigida ou substituída.

Voltando aos modelos, ao pinçar os atributos centrais da consciência (elencadas na terceira seção) e confrontá-los com os modelos, o que transparecerá? Sob vistas mais atentas, parece náo haver relação entre, por exemplo, intencionalidade e atividades neurais no córtex pré-frontal, porque não existem evidências confiáveis; há apenas algumas correlaçôes que divergem conforme se repetem os experimentos - uma mudança na marca dos aparelhos de medição, na calibragem e programação dos mesmos, nos pressupostos teóricos, e hipóteses de trabalho, mudam os dados (cf. UTTAL, 2012, SULLIVAN, 2009).

$\mathrm{Na}$ verdade, os modelos silenciam sobre essas propriedades típicas de estados conscientes. Os modelos são, no máximo, representações teóricas de certas nuances neurobiológicas e aspectos cognitivos. Há pouca experimentação ou replicação dos experimentos que sirvam de sustentação aos modelos. Modelos científicos precisam de base teórica forte e dados empíricos para que possam funcionar; os modelos neurais não satisfazem àqueles requisitos, porque são meros postulados teóricos, possuindo pouca relação com o conceito de consciência. Intencionalidade e qualia são propriedades típicas de alguns estados conscientes. Onde ficam essas propriedades, nos modelos?

As neurociências engatinham nos estudos sobre a consciência, e esse fato deve ser admitido. Até o momento, não existe um modelo ou teoria que explique causalmente e prediga como estados conscientes podem ocorrer. O cérebro é uma estrutura altamente complexa, com diversos níveis de organização. Por ora, as neurociências estão debruçadas apenas sobre a ponta do iceberg, e, apesar disso, é curioso o modo como já existem defensores da tese 
de que o cérebro é o real causador de comportamento consciente. Não se exige a identidade biunívoca entre eventos neurobiológicos e eventos conscientes, mas apenas a admissão de que os modelos possuem limites e podem estar excluindo outros aspectos subavaliados.

Além disso, a tese fisicalista implícita (o cérebro é físico) não é consensual, pois existem fisicalistas não-redutivos que são contra a redução total de estados conscientes a estados neurobiológicos (VAN RIEL, 2014). De modo breve, não há acordo sobre a natureza do cérebro e da consciência; tanto fisicalistas radicais quanto fisicalistas não-redutivos precisam de uma teoria ontológica robusta sobre a natureza do cérebro e da consciência. Há consenso sobre a necessidade de um cérebro organizado para implementar estados conscientes, porém, se esses estados são idênticos aos estados do cérebro ou são propriedades emergentes resultantes do trabalho do cérebro é uma disputa em aberto e, por essa razão, é prematuro defender certas posiçóes. Em tais moldes, os modelos servem de ponto de partida e descrevem mecanismos neurobiológicos específicos localizados em níveis mais básicos (cognitivo, sistêmico, celular, molecular). Esses níveis servem de base inicial onde processos causais ocorrem, e requerem explicaçôes multinível. É necessário admitir que podem existir outros níveis intermediários excluídos nos modelos ou não detectados.

O diagnóstico leva à conclusão de que se está ainda, na primeira fase (ou fase pré-paradigmática, em termos kuhnianos) da chamada "ciência da consciência”, no estágio de brainstorming, de levantamento de hipóteses, formulação e esclarecimento de conceitos, e construção de modelos. Os modelos são esboços iniciais e carecem de mais apoio teórico e experimental. A próxima fase consiste de testes e readequação e/ou unificação dos modelos segundo novas evidências, e a tentativa de formulação de uma teoria minimamente plausível da consciência que integre as propriedades da consciência e sua neurobiologia. Estados conscientes náo podem ser igualados, pelo menos por enquanto, a estados neurobiológicos, sem que se apontem os elos entre ambos.

É possível que estados conscientes sejam, de fato, eventos neurobiológicos, mas o reconhecimento disso requer a identificação de processos causais de modo mais explícito e com amplo apoio empírico. Os modelos compartilham os mesmos princípios e, em vez de concorrerem entre si, deveriam ser unificados em um modelo mais robusto que sirva de suporte para as pesquisas. Todavia, como se está na fase inicial de brainstorming, modelos semelhantes que se referem a um mesmo fenômeno são propostos e competem entre si. No entanto, os modelos parecem não atacar o cerne 
do problema, e a pergunta permanece: os modelos explicam como de fato o cérebro produz estados conscientes e suas propriedades?

\section{LimitaÇÓES dos Modelos}

O modelo de DNA, por exemplo, explica (aponta causas) diferentes tipos de variaçóes genéticas, mutação, doenças sindrômicas, e a transmissão dos caracteres genéticos às próximas geraçôes. A teoria subjacente ao modelo de DNA se mostra capaz de indicar causalmente, como certos tipos de doenças ou traços podem existir. Além disso, consegue unificar alguns fenômenos dispersos e predizer, com certo grau de probabilidade, a ocorrência de algumas doenças segundo a presença de determinados genes. No entanto, consideremse os modelos propostos de consciência: que tipo de entidades e propriedades eles explicam? Por exemplo, dizem algo sobre a subjetividade, intencionalidade e qualia? Sáo capazes de predizer o comportamento consciente? Estáo os modelos preenchendo a lacuna entre o nível neurobiológico e o nível fenomenal subjetivo? Não parece exagero afirmar que redes neurais em atividade sincronizadas produzem a consciência? Não seria, nesses casos específicos, uma relação de dependência, no sentido de que essas redes neurais suportam estados conscientes e, como tal, estados conscientes são dependentes da neurobiologia, porém, não determinados por ela? Identificar correlatos neurais é o mesmo que explicar estados conscientes? Não seria uma relação de interdependência? Se os modelos conseguem isso, seus autores deveriam indicar como e responder às perguntas acima.

Os modelos abordados aqui apenas descrevem alguns mecanismos neurobiológicos que são necessários para a ocorrência de estados conscientes, entretanto, tais modelos são insuficientes para explicar como estados neurobiológicos se transformam ou originam estados subjetivos. O modelo de Dennett é incompleto, porque não é capaz de abordar sequer a consciência de acesso, visto que, para Dennett, a palavra "acesso" requer um sujeito que acessa algo; mas não há "ninguém no comando", como defende o autor. Dennett nega a existência daquilo que mais interessa: a subjetividade e a qualidade de estados conscientes. $\mathrm{O}$ modelo dennettiano é meramente cognitivo e explica, no máximo, as funçôes cognitivas e perceptivas. Porém, é preciso certo esforço para aceitar a história do autor. Portanto, o modelo não parece satisfazer a condição de tentar explicar ou indicar os caminhos de entender como qualia, intencionalidade e subjetividade ocorrem. 
O modelo de Damásio, embora possua certa plausibilidade, peca por introduzir uma espécie de truque, algo como mágica: hocus pocus e pronto; propriedades fenomenais emergem de eventos neurobiológicos. É preciso também algum esforço para admitir que um self emerge de processos neurobiológicos. Os modelos de Freeman e Edelman também possuem certa razoabilidade, porque reconhecem que o cérebro é um sistema dinâmico auto-organizado; mas prescindem de uma racionalidade mínima, um agente consciente que delibera e pensa. A meu ver, a mera capacidade de integrar informação não explica propriedades superiores fenomenais e nem agência racional. Um computador é capaz de executar isso, e nem por esta razão se atribui consciência a ele. O modelo de Baars e Dehaene, a despeito de ser amplamente aceito, ainda náo consegue explicar a emergência de qualia. Como Ned Block (2005) afirma, no máximo, esses modelos explicam a consciência de acesso, i.e., como a informação sensorial é acessada pelo sujeito depois de processada por diversas redes neurais. Porém, o modelo em si não explica como essa informação adquire qualidades subjetivas únicas. Acessibilidade não equivale à subjetividade e suas qualidades intrínsecas.

Outro problema recorrente não somente nos modelos, mas também no vocabulário das neurociências, é o emprego indefinido do conceito de "informação". O que significa dizer que o cérebro ou redes neurais processam "informação"? Estritamente falando, o cérebro ou os neurônios processam estímulos físico-químicos e ponto. Sistemas sensoriais captam estímulos físico-químicos no meio e, através do processo de transdução, convertem em sinal neural, i.e., em linguagem eletroquímica que neurônios trabalham. Qual a relação entre eletroquímica e o conceito de informação?

É possível argumentar que os sinais eletroquímicos carregam informação captada no meio, assim como símbolos (numa mensagem) carregam informação sobre estados de coisas segundo a probabilidade condicional de um conhecedor entender o símbolo contido na mensagem (uma teoria proposta por Dretske, 1981). Mas, nesse caso, o "entendedor" é um agente consciente, no caso de neurônios, não está claro como eles "entendem" ou "representam" informação. Ainda assim, é apenas uma suposição problemática que pode ser aceita ou não. $\mathrm{O}$ fato é que o cérebro (ou neurônio) processa apenas sinais neurais (quantidades de energia) e ponto. A informaçáo parece emergir no nível fenomenológico, quando esse sinal neural recebe as qualidades típicas e o sujeito é capaz de acessá-la. Entretanto, mesmo essa hipótese é apenas uma hipótese que requer confirmação. 


\section{Observaçóes Finais: Rumo a uma Ciência da Consciência}

É preciso esclarecer que não há uma objeçáo ao uso de modelos ou mesmo indisposição com a prática neurocientífica. Pelo contrário, a atitude aqui é favorável ao empreendimento neurocientífico, mas a aceitação da limitação e incompletude dos modelos de consciência e a exigência de aperfeiçoamento deve ser considerada; na verdade, a unificação dos modelos em um único seria um bom caminho. Sou totalmente favorável à ideia de que é melhor um modelo incompleto do que nenhum. No entanto, os modelos existentes precisam de desenvolvimento. Do ponto de vista formal, parecem completos, porém, ao serem confrontados com a realidade, eles se mostram simplistas.

O problema da consciência não se resolverá explicando-se (reduzindo-se às partes) as qualidades superiores, citando-se apenas eventos neurobiológicos. É necessário algo mais, ${ }^{14}$ e esse "algo mais" exige tipos especiais de explicação multinível (funcional, intencional, teleológica e racional.). Na verdade, por mais que o neurocientista afirme que a experiência consciente consista apenas de processos neurobiológicos ocorrendo em níveis mais básicos no cérebro (o que é real), essa experiência parece não ser passível de ser explicada somente em termos físico-químicos ou igualada a tais processos neurobiológicos, embora esse tipo de explicação seja adequada, nesse nível, e faça parte - seja o suporte de uma explicação mais completa, incluindo o nível fenomenológico.

A explicação neurobiológica é tipicamente redutiva e costuma empregar o vocabulário da física e química. Não obstante a experiência consciente necessite de sistemas sensoriais bem adaptados e do cérebro, estes, porém, parecem não ser condiçóes suficientes para explicar a emergência de qualidades subjetivas vivenciadas no nível fenomenal. Essas propriedades emergem da experiência consciente e inexistem nas estruturas mais baixas do cérebro. Os modelos propostos náo conseguem acomodar isto. A explicação neurobiológica, embora válida, não é capaz de explicar a totalidade das qualidades surgidas.

Além disso, parece um fato inegável que há um "sujeito da experiência", i.e., o autor que vivencia as propriedades qualitativas (um sujeito), e não o cérebro. O cérebro é um órgão, assim como o coração e o estômago, os quais possuem funçóes exclusivas. Seria um erro categorial atribuir ao estômago o

${ }^{14}$ Enfatizo que o "algo mais" não implica a existência de uma entidade sobrenatural, mas a possível identificação de algum nível perdido, entre o psicológico e o neurobiológico. 
predicado "está com fome” ou ao coração “está apaixonado". Salvo que seja em contextos específicos, o uso desses predicados refere-se tipicamente a pessoas (sujeitos com intençóes, desejos, crenças). Analogamente, atribuir ao cérebro predicados pessoais como "decide, pensa, ou está consciente" é um erro categorial (HACKER; BENNETT, 2003), pois o cérebro é apenas um órgão. Certamente, o cérebro é a estrutura necessária para se vivenciar estados subjetivos, mas não parece ser suficiente.

Do lado da filosofia, tem havido tentativas de salvaguardar para si o fenômeno da consciência, através da atribuição de um estatuto especial nãofísico, como foi proposto por David Chalmers (1996), Frank Jackson ${ }^{15}$ (1982) e Thomas Nagel (1974). A dedução dos escritos desses autores leva a crer que "consciência" é uma propriedade não-física irredutível à neurobiologia. Chalmers vai mais além e ressuscita Descartes, defendendo explicitamente uma versão de dualismo, o qual ele denomina dualismo de propriedades. Segundo o autor, só existe uma substância no mundo, que é física, mas essa substância instancia dois tipos de propriedades: físicas, como o cérebro, e não-físicas, como a consciência. No entanto, Chalmers encara o mesmo problema de Descartes, a saber, como ocorre a relação e também como ocorre a instanciaçáo? Todavia, o autor não apresenta um argumento convincente em favor da tese dualista. Essa posição é indefensável e não cabe refutá-la aqui, tendo em vista que isso foi feito em outro lugar (cf. DE SOUSA, 2009).

O fato a se explicitar é que muitos filósofos têm ignorado a natureza biológica da consciência; acima de tudo, a consciência é um fenômeno baseado na neurobiologia; poucos filósofos admitem que estados conscientes são implementados ou causados pelo cérebro (de modo ainda desconhecido), um órgão altamente complexo e organizado em diversos níveis, que se caracteriza pela adaptabilidade aos estímulos físico-químicos ambientais e que foi selecionado por processos evolutivos. Diante disso, é fundamental assumir que o ponto de partida para a resolução ou entendimento do problema é aceitar que neurobiologia é a condição necessária para se vivenciar estados conscientes qualitativos. Decerto, a assunção não significa sustentar que, a partir de evidências neurobiológicas disponíveis limitadas, se possa imaginar que o problema está sendo resolvido; pelo contrário, essas evidências indicam

\footnotetext{
${ }^{15}$ Apesar de Jackson ter revisado suas crenças acerca do problema, reconsiderando que os qualia são, em última instância, físicos, pois o cérebro é um órgão físico e, portanto, o fisicalismo tem de estar certo (LUDLOW; NAGASAWA; STOLJAR, 2004).
} 
que está havendo certo entendimento de como eventos neurobiológicos funcionam como base necessária para a emergência de estados conscientes.

Em outras palavras, o que tem sido proposto é uma plataforma geral possibilitadora de entendimento comum, que é a neurobiologia, visto que, em última instância, seres humanos são sistemas biológicos dinâmicos, produto de processos evolucionários. Seres humanos, como todos os organismos na Terra, evoluíram tendo de lidar com um conjunto de limitaçóes e obstáculos, os quais devem ser levados em consideração, nesse contexto. Entretanto, desse entendimento, não surge a compreensão de como o cérebro produz consciência; entender a neurobiologia subjacente é o caminho, mas a neurobiologia por si não consegue, por ora, explicar como estados conscientes ocorrem.

Em resumo, a explicação da consciência citando apenas o nível neurobiológico parece incompleta, apesar de ser o ponto de partida (condição necessária). A razão consiste em ignorar o nível intencional psicológico e seus conteúdos (crenças, motivos, razōes,) que podem ter papel explicativo no comportamento de um agente. Os modelos de consciência servem apenas como representação parcial de um fenômeno complexo, o qual deve ser investigado sob diversos ângulos, e não apenas se privilegiando um, como o nível neurobiológico ou cognitivo. Os modelos nos servem como polo norteador e, como o próprio nome diz, são "modelos" e não descriçốes completas de como o cérebro produz consciência. Um modelo de furacão não é um furacão (uma representação fidedigna), e representa alguns aspectos do fenômeno, assim como modelos de consciência não são a consciência; eles representam alguns aspectos relacionados com o fenômeno. Os modelos são fundamentais para se entender o funcionamento do cérebro, mas é imperioso admitir suas limitaçóes inerentes, pois modelos são representaçóes simplificadas de um fenômeno e servem como ponto de partida para explicar e compreender algo geralmente complexo.

Embora existam diversas tentativas de reduzir a consciência a processos neurais, estes, contudo, não são suficientes para explicar causalmente a ocorrência da qualidade subjetiva de saborear a água de coco ou ouvir a Nona de Beethoven. Considerar somente a explicação neurobiológica é um erro, porque esta é incapaz de explicar (indicar causalmente) a emergência da consciência e das propriedades qualitativas. A neurobiologia é o nível necessário para se entender como estados qualitativos emergem no cérebro. Os modelos, apesar da incompletude e limitação, são o estágio inicial para a compreensão do problema da consciência. É melhor um modelo limitado do que nenhum. 
SOUSA, Carlos Eduardo B. Neural Models of Consciousness: a neurophilosophical analysis. Trans/Form/Ação, Marília, v. 38, n. 2, p. 95-128, Maio/Ago., 2015.

\begin{abstract}
Neurocognitive models are proposed in order to study the problem of consciousness. The models are attempts to answer the question of how the brain can generate conscious and qualitative states. Models are theoretical representations based on empirical data. Nonetheless, the central question concerns the reliability and the representativeness of the models, i.e., whether they in fact represent what they are supposed to explain, viz., how consciousness can emerge from neuronal processes. Such models are taken to be a guide for the scientific study of consciousness. Presently, there are six models: the multiple draft (Dennett), the global workspace (Baars), the dynamic core (Edelman), the global neuronal workspace (Dehaene et al.), the somatic markers hypothesis (Damásio), and the neurodynamic model (Freeman). This text is a survey and a philosophical analysis of the models of consciousness, and it considers their plausibility and coherence. I will concentrate on two points: (1) whether the neuroscientific models are able to explain 'consciousness' and its properties in neural terms, or whether the models only explain the neural correlates of conscious states, and (2) the scope, limitations and applicability of the models in the attempt to solve the problem of consciousness.
\end{abstract}

KEYWORDS: consciousness. neuroscientific models. explanation. neurobiology.

\title{
REFERÊNCIAS
}

ARMSTRONG, D. M. A Materialist theory of the mind. New York: Routledge, 1993.

BAARS, B. J. A Cognitive theory of consciousness, New York: Cambridge University Press. 1988.

In the theater of consciousness: the workspace of the mind. New York: Oxford University Press, 1997.

. The conscious access hypothesis: origins and recent evidence. Trends in Cognitive Sciences, v. 6, n. 1, p. 47-52. 2002.

BEAR, M. F. et al. Neuroscience: exploring the brain. Philadelphia, PA: Lippincott Williams \& Wilkins, 2007.

BICKLE, J. Philosophy and neuroscience: a ruthlessly reductive account. Dordrecht: Kluwer Academic Publishers, 2003.

BLACKMORE, S. J. Conversations on consciousness: what the best minds think about the brain, free will, and what it means to be human. Oxford: Oxford University Press, 2006.

BLOCK, N. Two neural correlates of consciousness. Trends in Cognitive Sciences, v. 9, n. 2, p. 46-52, 2005.

CHALMERS, D. The Conscious mind: in search of a fundamental theory. New York: Oxford University Press, 1996.

CHAO, H.-K.; CHEN, S.-T.; MILLSTEIN, R. L. Mechanism and causality in biology and economics. Dordrecht: Springer, 2013. 
CHURCHLAND, P. S. The Hornswoggle problem. Journal of Consciousness Studies, v. 3, p. 402-408, 1996.

Wilkins, 1998.

What should we expect from a theory of consciousness? Lippincott: Williams and

CRICK, F. The Astonishing hypothesis: the scientific search for the soul. New York: Scribner; Maxwell Macmillan International, 1994.

; KOCH, C. A Framework for consciousness. Nature Neuroscience, v. 6, n. 2, p. 119-126, 2003.

DAHLBOM, B. (Ed.). Dennett and his critics: demystifying mind. Oxford: Blackwell, 1995.

DAMÁSIO, A. R. O Mistério da consciência: do corpo e das emoçóes ao conhecimento de si. Sao Paulo: Companhia das Letras, 2005.

DE SOUSA, C. E. B. Neurociência da racionalidade versus racionalidade da neurociência: uma análise crítica a partir da filosofia das neurociências. Revista Ciências \& Cognição, v. 19, n. 3, 2014.

. Sobre a possibilidade de uma ciência da consciência. In: CARVALHO, Marcelo; FIGUEIREDO, Vinicius (orgs.). Filosofia contemporânea: lógica, linguagem e ciência. São Paulo: Anpof,, 2013. 7371.

Redução nas ciências especiais: o caso da neurociência. In: DUTRA, Luiz H. de A.; LUZ, Alxandre M. (Orgs.). Temas de filosofia do conhecimento. Florianópolis: UFSC/ Núcleo de Epistemologia e Lógica, 2011. p. 202-218. Trabalhos apresentados no VII Simpósio Internacional Principia. (d,. Disponível em: < http://www.cfh.ufsc.br/ $\sim$ nel/ rumos-vol11-ebook.pdf >. The Nature of Qualia: a neurophilosophical analysis. 2009. Thesis (Phd Dissertation) - Universität Konstanz, Germany, 2009. Disponível em < http://nbn-resolving.de/urn:nbn:de:bsz:352-opus-83788 >.

DEHAENE, S. Consciousness and the brain: deciphering how the brain codes our thoughts. New York: Viking Penguin Group, 2014.

; CHANGEUX, J.-P.; NACCACHE, L.; SACKURA, J.; SERGENT, C. Conscious, preconscious, and subliminal processing: a testable taxonomy. Trends in Cognitive Sciences, v. 10, n. 5, p. 204-211, 2006.

; NACCACHE, L. Towards a cognitive neuroscience of consciousness: basic evidence and a workspace framework. Cognition, v. 79, n. 1-2, p. 1-37, 2001.

; SERGENT, C.; CHANGEUX, J.-P. A Neuronal network model linking subjective reports and objective physiological data during conscious perception. Proceedings of the National Academy of Sciences of the United States of America, v.100, n. 14, p. 85208525, 2003.

DEL CUL, A.; BAILLET, S.; DEHAENE, S. Brain dynamics underlying the nonlinear threshold for access to consciousness. PLoS Biology, v. 5, n.10, p. e260, 2007. 
DENNETT, D. C. Consciousness explained. Boston: Little, Brown and Co., 1991.

. Sweet dreams: philosophical obstacles to a science of consciousness. Cambridge, MA: MIT Press, 2005.

. Heterophenomenology reconsidered. Phenomenology and the Cognitive Sciences, v. 6, p. 247-270, 2007.

DRETSKE, F. Knowledge and the flow of information. Cambridge, MA: The MIT Press, 1981.

EDELMAN, G. M. The Remembered present: a biological theory of consciousness. New York: Basic Books, 1989.

; TONONI, G. A Universe of consciousness: how matter becomes imagination. New York: Basic Books, 2000.

FEIGL, H. The "mental" and the "physical": the essay and a postscript. Minneapolis: University of Minnesota Press, 1967.

FREEMAN, W. J. How brains make up their minds. New York: Columbia University Press, 2001.

FRIGG, R.; HARTMANN, S. Models in Science. In: ZALTA, Edward N. (Ed.). The Stanford Encyclopedia of Philosophy. Winter 2012 Edition. Disponível em: < http://plato. stanford.edu/entries/models-science/>. Acesso em: 21/08/2013.

HACKER, P. M. S.; BENNETT, M. R. Philosophical foundations of neuroscience. Massachusetts: Wiley-Blackwell. 2003.

JACKSON, F. Epiphenomenal Qualia. The Philosophical Quarterly, v. 32, n. 127, p. 127136, 1982.

LUDLOW, P.; NAGASAWA, Y.; STOLJAR, D. There's something about mary: essays on phenomenal consciousness and Frank Jackson's Knowledge argument. Cambridge, MA: The MIT Press, 2004.

MCGINN, C. The mysterious flame: conscious minds in a material world. New York: Basic Books, 1999.

NAGEL, T. What is it like to be a bat? The Philosophical Review, v. 83, n. 4, p. 435-450, 1974.

PLACE, U. T. Is consciousness a brain process? British Journal of Psychology, v. 47, n. 1, p. 44-50, 1956

PURVES, D. Principles of cognitive neuroscience. Sunderland, MA: Sinauer Associates, 2008.

REVONSUO, A. Consciousness: the science of subjectivity. New York: Psychology Press, 2010 . 
Inner presence: consciousness as a biological phenomenon. Cambridge, MA: MIT Press, 2006.

SEARLE, J. R. The Rediscovery of the Mind. Cambridge, Massachusetts: The MIT Press, 1992.

. Consciousness. Annual Review of Neuroscience, v. 23, n. 1, p. 557-578, 2000.

. Consciência e linguagem. São Paulo: Martins Fontes, 2010.

SHEPHERD, G. M. Foundations of the neuron doctrine. New York: Oxford University Press, 1991.

SINGER, W. Synchronization of cortical activity and its putative role in information processing and learning. Annual Review Physiology, v. 55, p. 349-374, 1993.

. Neuronal synchrony: a versatile code for the definition of relations? Neuron, v. 24, p. 49-65, 1999.

; GRAY, C. M. Visual feature integration and the temporal correlation hypothesis. Annual Review of Neuroscience, v. 18, p. 555-586, 1995.

SMART, J. J. C. Sensations and brain processes. Philosophical Review, v. 68, p. 141-156, 1959.

SULLIVAN, J. The Multiplicity of experimental protocols: a challenge to reductionist and non-reductionist models of the unity of neuroscience. Synthese, v. 167, p. 511-539, 2009.

TUGENDHAT, E. Selbstbewußtsein und Selbstbestimmung: Sprachanalytische Interpretationen. Frankfurt am Main: Suhrkamp Verlag, 1997. Auflage: 8.

UTTAL, W. R. Reliability in cognitive neuroscience: a meta-meta-analysis. Cambridge, MA: The MIT Press, 2012.

VAN RIEL, R. The Concept of reduction. Heidelberg: Springer Verlag, 2014.

VELMANS, M. Understanding consciousness. 2. ed. New York: Routledge. 2009.

WATSON, J. B. Psychology as the behaviorist views it. Psychological Review, v. 20, p. 158-177, 1913. Publicada pela revista Temas em Psicologia v.16 n. 2, Ribeirão Preto 2008. Versão em português disponível em < http://pepsic.bvsalud.org/scielo.php?pid=S1413389X2008000200011\&script=sci_arttext\#txtnota4 >. Acesso em: 23 jul. 2014.

WITTGENSTEIN, L. Werkausgabe in 8 Bänden. Frankfurt am Main: Suhrkamp, 1984.

WOMELSDORF, T.; SCHOEFFELEN, J.-M.; OOSTENVELD, R.; SINGER W., DESIMONE, R.; ENGEL, A. K.; FRIES, P. Modulation of neuronal interactions through neuronal synchronization. Science, v. 316, p. 1609-1612, 2007.

ZEMAN, A. Consciousness: a user’s guide. Yale: Yale University Press, 2004.

Recebido / Received: 01/10/2014

Aprovado / Approved: 10/11/2014 
SOUSA, C. E. B. 